\title{
Distribution of ETBE-degrading microorganisms and functional capability in groundwater, and implications for characterising aquifer ETBE biodegradation potential
}

\author{
Henry C. G. Nicholls ${ }^{1}$ - Stephen A. Rolfe ${ }^{2}$ Helen E. H. Mallinson ${ }^{1}$ - Markus Hjort ${ }^{3}$ - Michael J. Spence ${ }^{3,5}$. \\ Matthijs Bonte ${ }^{3,4,6}$. Steven F. Thornton ${ }^{1}$ (I)
}

Received: 12 April 2021 / Accepted: 19 July 2021 / Published online: 4 August 2021

(C) The Author(s) 2021

\begin{abstract}
Microbes in aquifers are present suspended in groundwater or attached to the aquifer sediment. Groundwater is often sampled at gasoline ether oxygenate (GEO)-impacted sites to assess the potential biodegradation of organic constituents. However, the distribution of GEO-degrading microorganisms between the groundwater and aquifer sediment must be understood to interpret this potential. In this study, the distribution of ethyl tert-butyl ether (ETBE)-degrading organisms and ETBE biodegradation potential was investigated in laboratory microcosm studies and mixed groundwater-aquifer sediment samples obtained from pumped monitoring wells at ETBE-impacted sites. ETBE biodegradation potential (as determined by quantification of the ethB gene) was detected predominantly in the attached microbial communities and was below detection limit in the groundwater communities. The copy number of $e t h B$ genes varied with borehole purge volume at the field sites. Members of the Comamonadaceae and Gammaproteobacteria families were identified as responders for ETBE biodegradation. However, the detection of the $e t h B$ gene is a more appropriate function-based indicator of ETBE biodegradation potential than taxonomic analysis of the microbial community. The study shows that a mixed groundwater-aquifer sediment (slurry) sample collected from monitoring wells after minimal purging can be used to assess the aquifer ETBE biodegradation potential at ETBE-release sites using this function-based concept.
\end{abstract}

Keywords Ethyl tert-butyl ether $\cdot$ Bioremediation $\cdot$ Aquifer microorganisms $\cdot$ Attached community $\cdot$ eth $B$ gene

Responsible Editor: Robert Duran

Steven F. Thornton

s.f.thornton@sheffield.ac.uk

1 Groundwater Protection and Restoration Group, Department of Civil and Structural Engineering, University of Sheffield, S1 3JD, Sheffield, UK

2 Department of Animal and Plant Sciences, Alfred Denny Building, University of Sheffield, S10 2TN, Sheffield, UK

3 Concawe, Boulevard du Souverain 165, 1160 Brussels, Belgium

4 Shell Global Solutions International B.V., Rijswijk2288GK, The Netherlands

5 Present address: British Geological Survey, Environmental Science Centre, Keyworth, Nottingham NG12 5GG, UK

6 Present address: Ministry of Infrastructure and Water Management, The Hague, The Netherlands

\section{Introduction}

Ethyl tert-butyl ether (ETBE) is a gasoline additive that belongs to a broader group of chemicals known as gasoline ether oxygenates (GEOs). GEOs are used in fuels to increase the octane rating, enhance fuel combustion and reduce emissions. Methyl tert-butyl ether (MTBE) is the most commonly used GEO worldwide, although ETBE is used increasingly in European markets, supporting the requirements of the EU Renewable Energy Directives (2009/28/EC) and greater use of biofuels. ETBE synthesised from (bio)ethanol meets this criteria and is added to gasoline formulations at up to $15 \mathrm{vol} \%$ (Schuster et al. 2012).

Accidental releases of ETBE into the subsurface environment, either as a pure chemical, or in a mixture (as found in gasoline formulations), can result in contamination of groundwater (Stupp et al. 2012; van der Waals et al. 2018). The potential for ETBE biodegradation in groundwater is determined largely by the presence and activity of organisms 
within the aquifer microbial community able to mineralise the parent compound. There are a limited number of organisms known to biodegrade ETBE (reviewed in Thornton et al. 2020) to completion, such as Aquincola tertiaricarbonis L108 (Rohwerder et al. 2006), or partially to tert-butyl alcohol (TBA), the intermediate metabolite of aerobic ETBE biodegradation, such as Rhodococcus sp. IFP 2042 (Le Digabel et al. 2013). The eth $A B C D$ gene cluster was identified as involved in ETBE biodegradation (Chauvaux et al. 2001). This gene cluster includes a cytochrome monooxygenase (ethB) that initiates the incorporation of molecular oxygen into ETBE. Transcriptional investigations revealed that this gene is upregulated in the presence of ETBE (Malandain et al. 2010). Therefore, the detection of the eth $B$ gene in aquifer microorganisms demonstrates the presence of aerobic ETBE biodegradation potential in groundwater at an ETBE-release site (Fayolle-Guichard et al. 2012; Kucharzyka et al. 2019; Kyselková et al. 2019). While ETBE biodegradation facilitated by eth $B$ is the best characterised route for aerobic biodegradation, other biodegradation pathways have been proposed, although the genes involved have not been identified (Rosell et al. 2012; Le Digabel et al. 2013; Gunasekaran et al. 2014).

The sampling of groundwater for both hydrochemical and microbiological analysis usually involves the collection of filtered, sediment-free water samples (Environment Agency 2003a, b; Imfeld et al. 2011; Hose and Lategan 2012; O'Dwyer et al. 2014; Korbel et al. 2017; USEPA 2017; Environmental Protection Authority 2019). The chemistry and microbiological community profile of groundwater in monitoring wells often differs significantly from groundwater in the adjacent aquifer (Kozuskanich et al. 2011; Sorensen et al. 2013; Roudnew et al. 2014). For these reasons, sampling protocols typically recommend pumping (purging) monitoring wells to reduce sample turbidity and draw fresh groundwater from the aquifer for sampling (Nielsen and Nielsen 2006; Harter et al. 2014; USEPA 2017). This approach aims to exclude the collection of aquifer sediment and obtain a groundwater sample that is considered representative of in situ conditions (Warren 2005; Cullimore 2007; Korbel et al. 2017). However, a significant proportion of microorganisms in the subsurface environment are attached to sediment/ mineral surfaces (Alfreider et al. 1997; Williamson et al. 2012; Gregory et al. 2014; Ugolini et al. 2014a; Thornton et al. 2016). Planktonic (suspended) bacteria in groundwater are typically present in much lower numbers than attached microorganisms, for example $10^{2}-10^{6}$ cells $\mathrm{mL}^{-1}$ and $10^{4}$ -

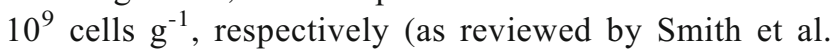
(2018)). There may also be significant differences in the physiology, composition, structure and activity between suspended and attached communities (Lehman et al. 2001, 2004; Rizoulis et al. 2013; Anantharaman et al. 2016; Thornton et al. 2016; Smith et al. 2018). Sampling only the groundwater can therefore under-represent, or even exclude, important information concerning the attached microbial community in aquifer biofilms (Alfreider et al. 1997; Rizoulis et al. 2013; Ugolini et al. 2014a; Smith et al. 2018). Furthermore, the relative abundance of bacteria and composition of the suspended microbial community can vary temporally in pumped groundwater samples (Kozuskanich et al. 2011; Sorensen et al. 2013; Roudnew et al. 2014). Given that the proportion of groundwater and aquifer sediment changes during purging of monitoring wells, bias may therefore occur in the sampling of organisms with different distributions between these components (Lehman 2007). This can lead to differences in measurements of microbial activity and functional capability, with incorrect interpretation of important functional processes within the aquifer microbial community (Alfreider et al. 1997; Lehman et al. 2004; Handley et al. 2012; Rizoulis et al. 2013; Korbel et al. 2017; Smith et al. 2018). These issues can limit the reliability of microbiological investigations where the origin of organisms in groundwater or the characterisation of aquifer organisms and microbial communities involved in contaminant biodegradation is of interest (Cullimore 2007; Lebron et al. 2011; Rizoulis et al. 2013; Somaratne and Hallas 2015; Thornton et al. 2016; Korbel et al. 2017).

To our knowledge, no studies have examined the physical location of ETBE-biodegrading activity in an aquifer, that is, the relative contribution of suspended and attached microbial communities to this potential. However, is it known that the taxonomy of attached and suspended microbial communities in aquifers can differ (Alfreider et al. 1997; Rizoulis et al. 2013; Hug et al. 2015; Smith et al. 2018; Fillinger et al. 2019). Interestingly, several studies have investigated the colonisation of functionally-important GEO-degrading organisms on inert surfaces used in bioreactors (Kharoune 2001; Purswani et al. 2011; Hicks et al. 2014; Alfonso-Gordillo et al. 2016; Guisado et al. 2016). These organisms were isolated from GEO-release sites and it is a reasonable hypothesis that they will preferentially attach to surfaces in aquifers. Sampling groundwater may therefore give an incomplete view of the overall potential for ETBE biodegradation due to these biases. The extent to which such biases are a problem is unknown. However, a strong preference for attachment would lead to a systematic under-sampling of these organisms in groundwater and inaccurate assessments of biodegradation potential.

The aim of this study was to determine the location of ETBE-degrading organisms and functional capability for ETBE biodegradation within groundwater and aquifer sediment fractions, to support the interpretation of ETBE biodegradation potential at ETBE-impacted sites. This is necessary where a microbiological assessment may be used in addition to the groundwater hydrochemical assessment that is normally undertaken at a gasoline-impacted site (ASTM 1998; Wiedemeier et al. 1999; Environment Agency 2000; API 
2007). This is also important given that different purging regimes may be implemented in the sampling process (Nielsen and Nielsen 2006; CL:AIRE 2008; Harter et al. 2014; USEPA 1996, 2017) and that for some aquifer settings (e.g. bedrock aquifers) it may only be possible to collect groundwater samples for microbiological characterisation (Itävaara et al. 2011; O’Dwyer et al. 2014; Ben Maama et al. 2015; Eriksson et al. 2016; Wu et al. 2016).

To achieve this, laboratory studies of ETBE biodegradation and aquifer samples collected from two ETBE-release field sites were investigated using quantification of the eth $B$ gene and culture-independent molecular analysis. Aerobic biodegradation of ETBE in the groundwater (planktonic) and aquifer sediment (attached) microbial communities was assessed in laboratory microcosm studies, and field samples from pumped monitoring wells at the ETBE-release sites were collected for comparison. All laboratory and field samples were processed to separate the planktonic and attached microbial communities, the location of ethB gene-containing organisms identified, and the microbial community composition analysed by high-throughput $16 \mathrm{~S}$ rRNA gene sequencing. Pumped groundwater samples were also collected from monitoring wells at the field sites after purging 1, 3 and 6 well volumes to assess the effect of purging protocols on the detection of ETBE-degrading organisms. To the best of our knowledge, this is the first study conducted using laboratory experiments, supported by field samples, to determine the location of ETBE-degrading organisms in ETBE-impacted aquifers.

\section{Materials and methods}

The experimental programme developed for this research is summarised in Fig. 1, which shows the laboratory and field studies at the different study sites, the respective sampling schedule and materials collected. The procedures used to process these samples are explained below.

\section{Field site geology, hydrogeology and sample collection}

Groundwater and aquifer sediment samples used to construct the microcosm experiments were collected from an ETBEimpacted site in France (Site F), as described in Nicholls et al. (2020). The aquifer comprised Quaternary alluvial deposits with up to $3 \mathrm{~m}$ sandy gravel loam underlain by gravel and sand, with a water table that fluctuates between 7 and 10 $\mathrm{m}$ below ground level. Two locations were selected to provide inocula for the laboratory experiments. These comprised a non-impacted location (F1), upgradient of the ETBEimpacted zone where ETBE and BTEX compounds were below detection limits, and an impacted location (F2) in the ETBE-impacted zone. Cored samples of aquifer sediment were collected by sonic drilling from these locations $(350 \mathrm{~m}$ apart). Groundwater samples were collected from monitoring wells installed in the aquifer at locations F1 and F2 after coring. These samples were collected in autoclaved glass bottles, filled completely and stored at $4{ }^{\circ} \mathrm{C}$ until used to establish microcosms (Fig. 1).

To evaluate the effect of well purging, slurry (mixed groundwater-aquifer sediment) samples were obtained from two field sites. At Site F in France a slurry sample was collected from monitoring wells F1 and F2 after 1, 3 and 6 purge volumes, using a submersible pump at a flow rate of $6 \mathrm{~L} \mathrm{~min}^{-1}$. The slurry samples were collected in autoclaved $500 \mathrm{~mL}$ glass bottles, filled completely and stored at $4{ }^{\circ} \mathrm{C}$. Neither well F1 nor F2 had detectable ETBE at the time of sampling (February 2019). The groundwater fraction from wells $F 1$ and $F 2$ was sampled for the analysis of inorganic determinands (Table S1).

Similar slurry samples were also collected from a second ETBE-impacted site in Turkey (Site T). At this site the aquifer comprises a $1 \mathrm{~m}$ surface clay layer underlain by $3-4 \mathrm{~m}$ sand and silt. The monitoring wells are installed at a maximum depth of 3-4 m, and the water table fluctuates between $1 \mathrm{~m}$ and $2.5 \mathrm{~m}$ below ground level. Slurry samples were obtained from pumped monitoring wells (T1-3) using a submersible pump at a flow rate of $0.3 \mathrm{~L} \mathrm{~min}^{-1}$, following the same purging regime and storage procedure used at Site F. The groundwater from all three wells contained ETBE at the time of sampling (November 2018): 7.4, 0.18 and $0.14 \mathrm{mg} \mathrm{L}^{-1}$ for T1, T2 and $\mathrm{T} 3$, respectively. The groundwater fraction from wells T1-3 was also sampled for the analysis of inorganic determinands (Table S1).

\section{Planktonic and attached microbial community microcosm experiments}

Large volume $(1 \mathrm{~L})$ laboratory microcosms were constructed with groundwater and aquifer sediment sampled at Site F (Fig. 1b), as described in Nicholls et al. (2020). A set of $50 \mathrm{~mL}$ microcosms, in which the planktonic and attached microbial communities were separated as in Fig. 1d, was then created from the $1 \mathrm{~L}$ microcosms containing inoculum sampled between 13-14 meters below ground level, using the following components:

1. ETBE-contaminated groundwater without microbial cells or sediment fines, obtained by filtration through a $0.2 \mu \mathrm{m}$ Whatman polycarbonate filter;

2. ETBE-contaminated groundwater with planktonic microbial cells but without sediment fines, obtained by filtration through a 5- $\mu \mathrm{m}$ Whatman polycarbonate filter;

3. Aquifer sediment with attached microbial cells, prepared by gently washing sediment with 2 volumes of $0.2 \mu \mathrm{m}$ filtered ETBE-contaminated water. 

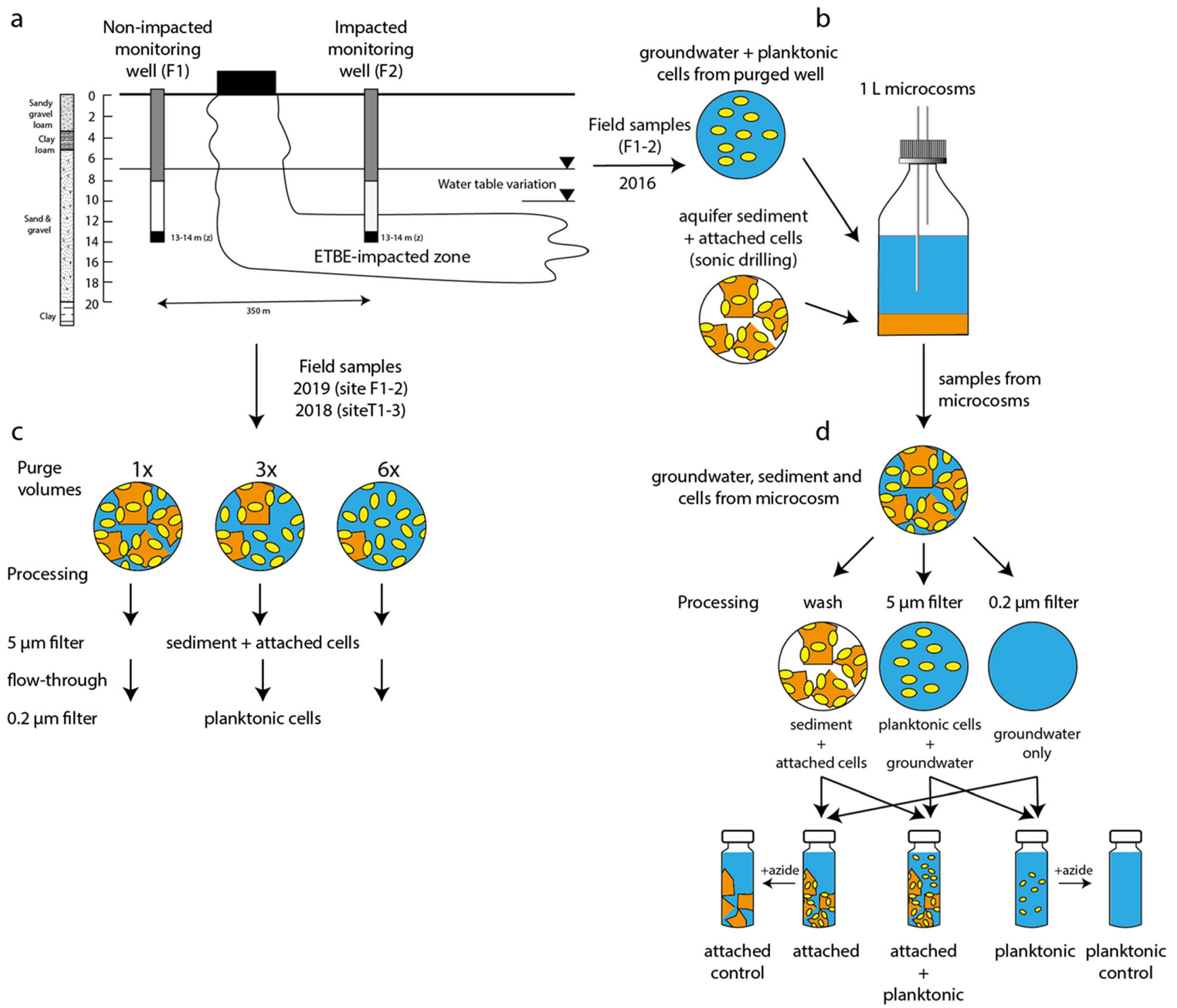

Fig. 1 A) Diagram of Site F with monitoring wells installed at locations impacted (F2) and not impacted (F1) by ETBE contamination. Samples $\mathrm{F} 1$ and $\mathrm{F} 2$ were taken from 13 to $14 \mathrm{~m}$ below ground level. B) Microcosms containing attached and planktonic cells were assembled using groundwater (from wells F1 and F2) and aquifer sediment sampled from cores (collected by sonic drilling) at a 4:1 ratio. C) Aquifer sediment and groundwater mixtures obtained from monitoring wells at Site F (F1 and F2) and Site T (T1, T2 and T3, not shown) from different purge volumes. Aquifer sediment + attached cells was collected on $5 \mu \mathrm{m}$ filters. Planktonic cells in the flow through were collected on $0.2 \mu \mathrm{m}$ filters. D)

"Planktonic" microcosms were prepared by mixing $20 \mathrm{~mL}$ of groundwater + planktonic cells (\#2) with an equal volume of groundwater without planktonic cells (\#1). "Attached" microcosms were prepared using $20 \mathrm{~mL}$ of washed aquifer sediment + attached cells (\#3) with an equal volume of groundwater without planktonic cells (\#1). Triplicate planktonic and attached microcosms were prepared in autoclaved $50 \mathrm{~mL}$ glass vials sealed with aluminium crimp-caps, with sterile controls created by adding $2 \mathrm{~g} \mathrm{~L}^{-1}(\mathrm{w} / \mathrm{v})$ sodium azide (Shah

Samples from B) were used to provide mixed groundwater + aquifer sediment. Groundwater without planktonic cells was obtained by filtration through a $0.2-\mu \mathrm{m}$ filter. Groundwater + planktonic cells was obtained by filtration through a $5 \mu \mathrm{m}$ filter. Sediment + attached cells was obtained by gently washing the sediment in $0.2 \mu \mathrm{m}$-filtered groundwater. These samples were used to establish $50 \mathrm{~mL}$ microcosms containing groundwater with planktonic cells only, attached cells only, or both attached + planktonic cells. Abiotic controls were created by the addition of sodium azide

et al. 2009). An additional biotic control ("Attached + Planktonic") to compare ETBE biodegradation in a mixed groundwater-sediment microcosm was created by mixing 20 $\mathrm{mL}$ of washed aquifer sediment + attached cells (\#3) with 20 $\mathrm{mL}$ of $5 \mu \mathrm{m}$-filtered ETBE-contaminated groundwater + planktonic cells (\#2). ETBE (99\% purity, Sigma) was added at a nominal concentration of $1.2-1.8 \mathrm{mg} \mathrm{L}^{-1}$. The microcosms were incubated in the dark at $12^{\circ} \mathrm{C}$ to reflect the mean groundwater temperature of European sites (Tissen et al. 
2019). Given the duration of the experiment ( $<30$ days), no significant fluctuation in the sample site groundwater temperature is expected over this timeframe.

Groundwater samples were taken at intervals for the analysis of ETBE. Prior to sampling all microcosms were removed from the incubator, mixed gently and placed at room temperature for one hour. A 1-mL groundwater sample was extracted using a sterile syringe and needle and analysed immediately using GC-MS ("Geochemical analysis" section). Once the experiment was complete planktonic microbial cells were harvested by filtering the groundwater through a $0.2 \mu \mathrm{m}$ filter (PES, Millex), which was then used for DNA extraction ("Molecular analysis of microcosms" section). DNA from attached cells was extracted directly from the aquifer sediment samples.

\section{Field samples}

Slurry samples obtained after the removal of different purge volumes in pumped monitoring wells at Site $\mathrm{F}$ and Site $\mathrm{T}$ were processed in a similar manner to samples from the microcosm experiments. Sample bottles were inverted to re-suspend all the sediment immediately prior to sampling. The slurry was filtered through a $5-\mu \mathrm{m}$ filter to capture the aquifer sediment and attached microbial cells (Fig. 1c). The groundwater and planktonic cells passing through this filter were collected in a sterile $50 \mathrm{~mL}$ Falcon tube and the planktonic cells then harvested from this liquid on a $0.2 \mu \mathrm{m}$ filter. Membranes were stored at $-80^{\circ} \mathrm{C}$ prior to DNA extraction.

\section{Geochemical analysis}

The chemical composition of groundwater samples was analysed using methods described in Nicholls et al. (2020). The analysis of ETBE and TBA was performed by solid phase micro-extraction (SPME) of the aqueous phase using a CombiPAL autosampler (CTC Analytics AG, Zwingen, Switzerland) connected to a Shimadzu QP1000 GC-MS. A $85 \mu \mathrm{m}$ Carboxen/PDMS StableFlex SPME fibre (Supelco, UK) was used for sample extraction, with an extraction time of $2 \mathrm{~min}$. The fibre was desorbed in the injection port of the GC-MS at $300{ }^{\circ} \mathrm{C}$ for $3 \mathrm{~min}$. The GC-MS was fitted with a 20 m DB-624 column (121-1324, Agilent Technologies Ltd), with an initial oven temperature of $40{ }^{\circ} \mathrm{C}$. The temperature programme was increased at $10^{\circ} \mathrm{C} \mathrm{min}^{-1}$ to $170{ }^{\circ} \mathrm{C}$, then at 40 ${ }^{\circ} \mathrm{C} \mathrm{min}^{-1}$ to $250^{\circ} \mathrm{C}$, then held for $2 \mathrm{~min}$, for a total run time of $17 \mathrm{~min}$. The column flow was $1.18 \mathrm{ml} \mathrm{min}^{-1}$, using Helium as the carrier gas, with a split ratio of 30:1. The GC-MS interface was set to $250{ }^{\circ} \mathrm{C}$, with the GC-MS ion source at $200^{\circ} \mathrm{C}$ and solvent cut time of 1.4 minutes. The MS programme was set to Scan/SIM mode, allowing for a full scan of the $\mathrm{m} / \mathrm{z}$ values 30 200 together with monitoring of selected ions corresponding to the retention times of each analyte. In addition to calibration standards, an internal standard containing deuterated isotopologues of the analytes of interest was also prepared. The internal standards were added to all samples prior to analysis. The peak area represented by the quantification ion was used to calculate the concentration of the analyte in the original sample. The ratio of the peak areas of the quantification and reference ions was used together with the retention time to identify the analyte peak, using GC-MSsolution V2 software (Shimadzu). Dissolved major ions were analysed using a Dionex 3000 instrument equipped with cation and anion modules for simultaneous detection, as described in Nicholls et al. (2020).

\section{Molecular analysis of microcosms}

DNA was extracted using a FastDNA Spin kit for Soil (MP Biomedicals, UK) according to the manufacturer's instructions, with an additional $10 \mathrm{~min}$ incubation at $65^{\circ} \mathrm{C}$ prior to homogenisation. DNA quantification was performed using a Qubit dsDNA HS Assay (ThermoFisher, UK).

\section{Quantitative real-time PCR (qRT-PCR)}

Absolute quantification of ethB and 16S rRNA genes was carried out using standards and qRT-PCR, as described in Nicholls et al. (2020).

\section{$16 \mathrm{~S}$ rRNA gene sequencing}

16S rRNA genes were amplified, purified and sequenced according to Nicholls et al. (2020). Each sample was amplified in triplicate to minimise PCR bias and pooled prior to sequencing using Illumina MiSeq. DNA sequences were supplied as demultiplexed FASTQ data files containing $250 \mathrm{bp}$ paired end sequences. Initial data processing was performed using Qiime2 (Bolyen et al. 2019) to produce a biom file of Operational Taxonomic Units (OTUs), abundances and taxonomy. Raw sequences were processed using dada2 to remove primers, chimeric sequences and produced paired sequences (Callahan et al. 2016). Samples contained between 12,209 and 254,448 reads after processing.

Sequences were aligned using MAFFT (Katoh et al. 2019) and a rooted phylogenetic tree produced using FastTree2 (Price et al. 2010). Sequences were classified using Scikitlearn (Pedregosa et al. 2011) trained against the V3-V4 regions of 16S rRNA genes in the SILVA132 database (Quast et al. 2012). Further analysis was performed in $R$ ( $R$ Core Team 2019). The Qiime2 biom artefact produced above was loaded into R using functions from the 'qiime2R' package and processed using the 'phyloseq' package (McMurdie and Holmes 2013). For analyses requiring even sampling depth, samples were normalised to 10,000 reads per sample. 


\section{Microscopy}

Total cell counts of planktonic bacteria were performed using $100 \mu \mathrm{L}$ of groundwater sample, mixed with $10 \mathrm{~mL}$ of $10 \mathrm{mM}$ $\mathrm{NaCl}$ and vacuum-filtered through a black $25.4 \mathrm{~mm}$ diameter, $0.2 \mu \mathrm{m}$ filter membrane (Whatman). Bacteria were stained using $200 \mu \mathrm{L}$ of $6 \mu \mathrm{M}$ SYTO 9 Green fluorescent dye (Thermo) and incubated in the dark for $15 \mathrm{~min}$. The cell counts were performed using a Leica DM6 fluorescence microscope. Cells were counted under a $40 \times$ objective and the mean counts in 5 randomly selected field of views are presented. Nicholls et al. (2020) showed previously that the proportion of live planktonic cells from the same sample site ranged between 48 and $82 \%$.

Images of aquifer sediment grains were acquired from 5 $\mu \mathrm{m}$ - and $0.2 \mu \mathrm{m}$-filtered slurry samples, respectively. Sediment grains were gently scraped from each membrane surface using a sterile scalpel and were gently mixed with 20 $\mu \mathrm{L}$ ultrapure water on a microscope slide. Bright field z-stack images were obtained using a Leica DM6 fluorescence microscope.

\section{Statistical analysis}

Statistical analysis was performed in $\mathrm{R}$ (version 4.03) (R Core Team 2020) using the linear model function ' $I m$ ' with interactions between location, pump volumes and filters. Only single samples could be obtained, hence comparisons were made between sites using the different wells (F1-F2, T1-T3) and filters $(0.2 \mu \mathrm{m}$ and $5 \mu \mathrm{m})$ as replicates. Molecular analyses were performed in triplicate, with the mean value of these technical replicates used for statistical analyses. Post-hoc comparisons were made using a Tukey test using the 'emmeans' package (Lenth 2021). All measurements were $\log$ transformed prior to analysis. If values were below the detection limit, then the detection limit was substituted before $\log$ transformation.

\section{Results}

\section{ETBE biodegradation potential in planktonic and attached microbial communities from microcosm experiments}

In the microcosm study described in Nicholls et al. (2020) groundwater and aquifer sediment was collected from two locations (F1-non-impacted and F2-ETBE-impacted) at Site $\mathrm{F}$ to examine the aerobic biodegradation of ETBE. At the time of sampling (October 2016) ETBE was detected only in well $\mathrm{F} 2\left(1.4 \mathrm{mg} \mathrm{L}^{-1}\right)$. These $1 \mathrm{~L}$ microcosms were incubated for 200 days with periodic re-addition of ETBE. The F2 microcosms from this experiment were then used to create 50
$\mathrm{mL}$ microcosms to assess the contribution of attached and planktonic cells in ETBE biodegradation (see Fig. 1).

The aquifer 'sediment + attached cells' fraction was prepared by gently washing the sediment with $0.2 \mu \mathrm{m}$ filtersterilised groundwater. DNA yields from the $1 \mathrm{~L} \mathrm{~F} 1$ and F2 microcosms were 13.4 and $51 \mathrm{ng} \mathrm{mL}^{-1}$, respectively. The 'planktonic cells' fraction was collected by filtration through a $5 \mu \mathrm{m}$ filter and capture on a $0.2 \mu \mathrm{m}$ filter. DNA yields were much lower $\left(0.01 \mathrm{ng} \mathrm{mL}^{-1}\right.$ in both cases). These observations implied that most microbial cells were attached to the sediment fraction in the microcosms. From this, we formulated the alternative hypotheses that (a) the majority of ETBEdegraders would therefore be attached, but with no differences in their relative abundance, or (b) that in addition to the numerical differences in cell numbers, the relative abundance of ETBE-degraders might also be altered.

ETBE was completely biodegraded after 23 days without a lag in the $50 \mathrm{~mL}$ 'Attached' microcosms containing the aquifer sediment and $0.2 \mu \mathrm{m}$ filter-sterilised ETBE-contaminated groundwater (Fig. 2a). ETBE biodegradation in the 'Attached' microcosms and 'Attached + Planktonic' microcosms (containing aquifer sediment and $5 \mu \mathrm{m}$-filtered ETBE-contaminated groundwater) was $90 \%$ completed within 10 days. No TBA was detected during ETBE biodegradation, presumably due to rapid consumption of this metabolite by the consortia (Nicholls et al. 2020). No ETBE biodegradation was observed in the 'Planktonic' microcosms (containing the planktonic cells and $0.2 \mu \mathrm{m}$ filter-sterilised ETBE-contaminated groundwater) or the abiotic controls (Fig. 2a and b). There was no detectable DNA yield from the 'Planktonic' microcosms (below detection limit of $0.01 \mathrm{ng} \mu \mathrm{L}^{-1}$ ), but comparable DNA yields from each 'Attached' microcosm. Similar results were found when $e t h B$ gene copy numbers were quantified using qRT-PCR (Fig. 2c). Therefore, the ETBE-degrading activity and associated organisms in these microcosms were found entirely in the microbial community attached to the aquifer sediment.

\section{ETBE biodegradation potential in planktonic and attached microbial communities in pumped groundwater samples from field sites}

Pumped groundwater samples, collected after purging of monitoring wells at Site F and Site T, were compared with the laboratory microcosm samples processed and filtered in the same way. The monitoring wells F1 and F2 at Site F which had been used for the $1 \mathrm{~L}$ and $50 \mathrm{~mL}$ microcosm experiments (see above) were re-sampled.

Microscopy confirmed that the $5 \mu \mathrm{m}$ filter captured most sediment grains in these field samples, with only a few fine grains $(<5 \mu \mathrm{m}$ ) in the $0.2 \mu \mathrm{m}$-filtered samples (Supplementary Figure 1). Cell counts also showed that the planktonic cells passed through the $5 \mu \mathrm{m}$ filter, as there was no reduction of 
Fig. 2 ETBE biodegradation in microcosms containing a) attached cells (circles) or attached + planktonic cells (triangles), or b) planktonic cells. Individual replicates are connected by lines. Live samples are shown as black symbols, whereas abiotic samples created by the addition of sodium azide are shown as white symbols. c) DNA yields and ethB gene copy numbers from replicate attached and planktonic microbial communities. BDL indicates below detection limit a

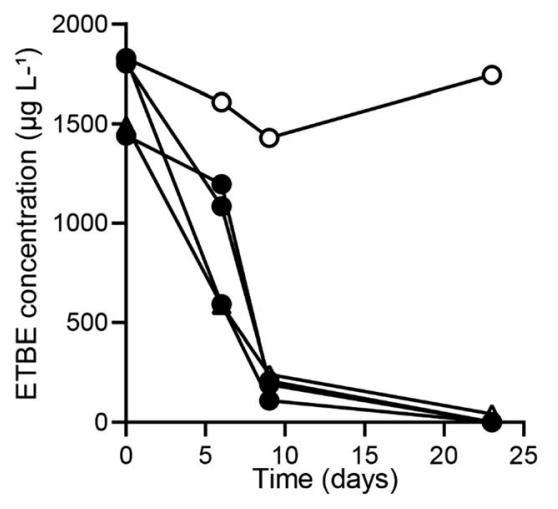

b

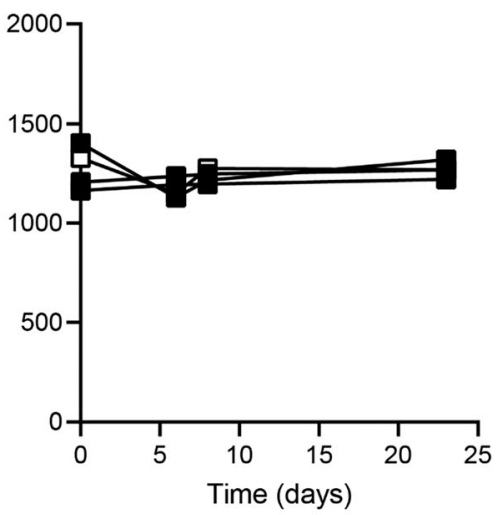

c

\begin{tabular}{lccccccc}
\hline Microcosm & \multicolumn{3}{c}{ Attached } & & \multicolumn{3}{c}{ Planktonic } \\
\cline { 2 - 4 } \cline { 6 - 8 } Replicate & 1 & 2 & 3 & & 1 & 2 & 3 \\
\cline { 2 - 5 } DNA yield $\left(\mathrm{ng} \mathrm{mg}^{-1}\right)$ & 1.9 & 1.8 & 1.5 & & BDL & BDL & BDL \\
ethB $($ copies mg-1) & $2.7 \times 10^{3}$ & $1.6 \times 10^{3}$ & $1.4 \times 10^{3}$ & & BDL & BDL & BDL \\
\hline
\end{tabular}

cell numbers in the planktonic phase after $5 \mu \mathrm{m}$ filtration (data not shown).

For all samples, more sediment was collected on the $5 \mu \mathrm{m}$ filter than the $0.2 \mu \mathrm{m}$ filter $(p<0.001)$ (Fig. 3). At Site F between 0.02 and $1.4 \mathrm{mg}$ of sediment was collected per $\mathrm{mL}$ of sample. More sediment was collected from monitoring well F2 than F1, and the amount of sediment collected on the $5 \mu \mathrm{m}$ filter decreased at monitoring well F2 as the number of purge volumes increased. The amount of fine sediment collected on the $0.2 \mu \mathrm{m}$ filter was lower and unaffected by purge volume. At Site T more sediment was collected $\left(0.25\right.$ to $\left.9.4 \mathrm{mg} \mathrm{mL}^{-1}\right)$ than at Site $\mathrm{F}(p<0.001)$ and the amount of aquifer sediment collected on the $5 \mu \mathrm{m}$ filter tended to decrease with increased purge volume, as expected from the purging process. While the aquifer sediment collected after purging 6 well volumes from monitoring well T3 was greater than that after purging 3 well volumes, this was still less than the first purge volume. This most likely reflects physical heterogeneity in the sediment size fractions sampled in the aquifer during pumping (Wu et al. 2013). However, in all wells at Site T, most aquifer sediment was collected after the first purge volume.

DNA could be extracted from all Site T samples and most of the $5 \mu \mathrm{m}$-filtered Site $\mathrm{F}$ samples analysed, but yields from $0.2 \mu \mathrm{m}$-filtered Site F samples were low or undetectable. DNA extracted from the $5 \mu \mathrm{m}$-filtered samples was derived solely from attached microbial cells, whereas DNA extracted from $0.2 \mu \mathrm{m}$-filtered samples was derived from both planktonic cells and microbes attached to fine $(<5 \mu \mathrm{m})$ sediment particles, as confirmed by microscopy (Supplementary Figure 1). DNA yields were higher from the $5 \mu \mathrm{m}$-filtered samples, both in absolute terms (Fig. 3b) and DNA yield per $\mathrm{mg}$ sediment $\left(\sim 7 \mathrm{mg}\right.$ DNA $\mathrm{mg}^{-1}$ sediment in $5 \mu \mathrm{m}$-filtered samples compared to $\sim 0.6 \mathrm{mg}$ DNA $\mathrm{mg}^{-1}$ sediment in 0.2 $\mu \mathrm{m}$-filtered samples) $(p<0.001)$. This indicates that a greater proportion of the microbial biomass was attached to larger sediment particles at both field sites. Generally, the greatest DNA yields were obtained from slurry samples collected after purging 1 or 3 well volumes, and less from samples collected after purging 6 well volumes, indicating that the early purge samples (up to 3 well volumes) are important for maximising DNA yields.

Total microbial numbers were estimated using the $16 \mathrm{~S}$ rRNA gene copy number as a proxy. At Site T microbial cell numbers were higher in the attached than planktonic phase $(p$ $=0.013$ ), often by several orders of magnitude (Fig. 3b), confirming that most of the microbial community in the aquifer sample originates from the attached organisms. Little or no DNA was recovered from the $0.2 \mu \mathrm{m}$-filtered samples at Site F, confirming that most organisms were also attached to the aquifer sediment at this site. Quantification of the ethB gene, as a measure of ETBE-degrading organisms, was also carried out to determine the location of these organisms. The ethB gene was below detection limit in samples from the nonimpacted well (F1) at Site F. It was detected only in $5 \mu \mathrm{m}$ filtered samples from well F2 at $\sim 10^{4}$ gene copies $\mathrm{mL}^{-1}$ for all purge volumes, although detection of the $\operatorname{eth} B$ gene was highest in the first purge volume. At Site $\mathrm{T}$, the eth $B$ gene was detected in wells T1 and T2 only, at $\sim 10^{4}-10^{5}$ copies $\mathrm{mL}^{-1}$. The gene was detected in all $5 \mu \mathrm{m}$-filtered samples from wells $\mathrm{T} 1$ and T2, all $0.2 \mu \mathrm{m}$-filtered samples from well T1, but only after 6 purge volumes for the $0.2 \mu \mathrm{m}$-filtered sample in well $\mathrm{T} 2$. Where the ethB gene was detected in both the attached and planktonic phases, it was present at several orders of magnitude 
a)

)
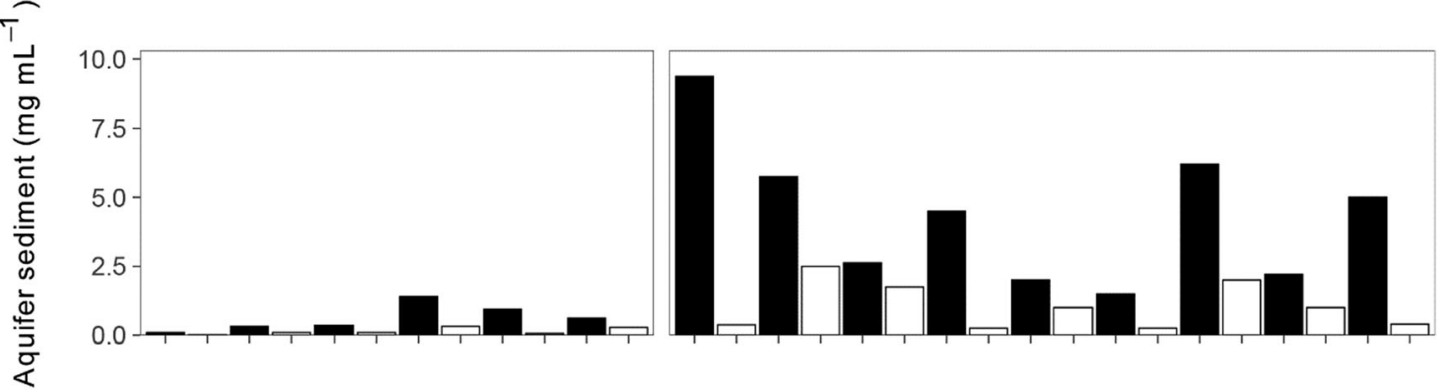

b)

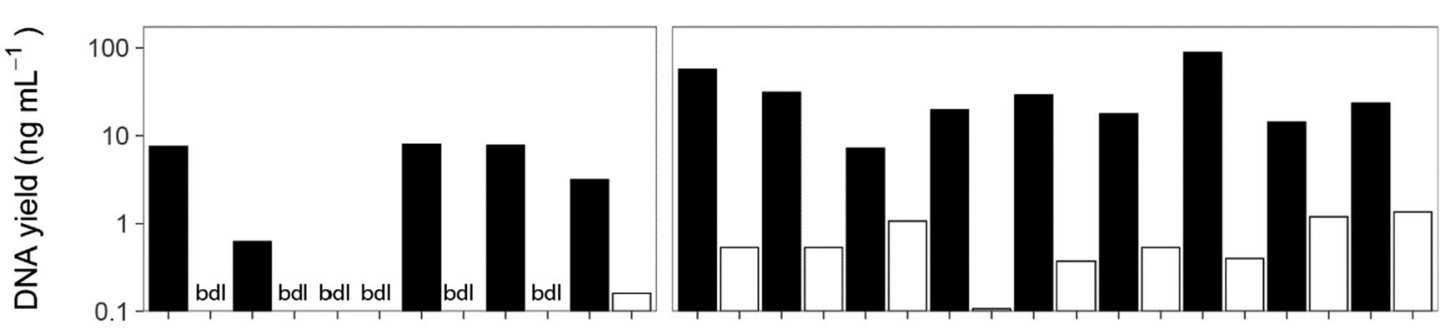

c) $\leftarrow$
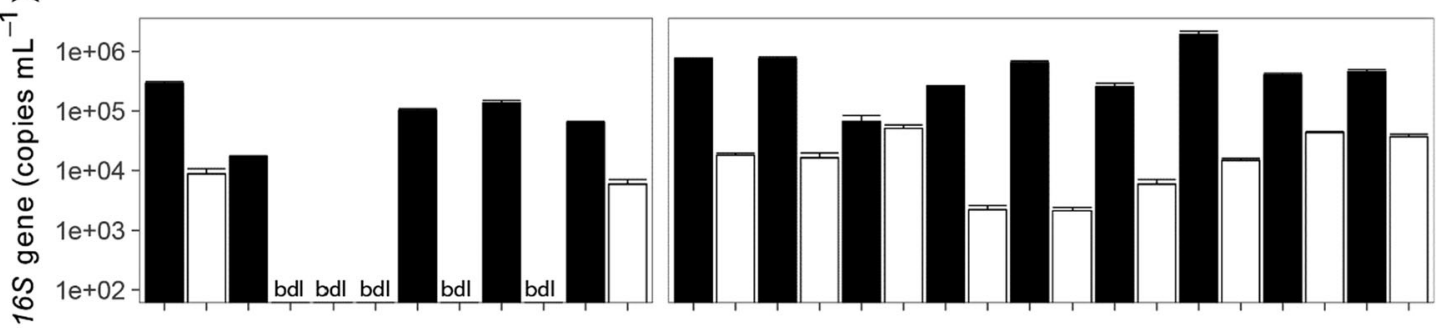

d)
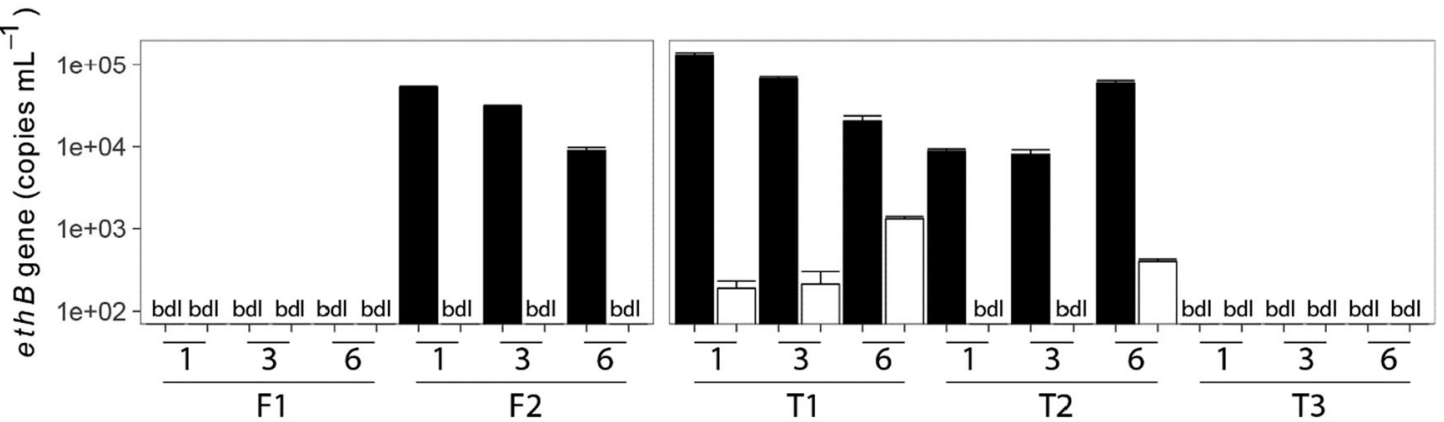

Fig. 3 Analysis of aquifer sediment collected from an un-impacted groundwater monitoring well (F1) and an ETBE-impacted groundwater monitoring well (F2) at Site F and three ETBE-impacted monitoring wells (T1-3) at Site T, after purging 1, 3 or 6 borehole volumes of groundwater which was filtered through a $5 \mu \mathrm{m}$ filter (black bars) followed by a $0.2-$ $\mu \mathrm{m}$ filter (white bars): (a) Concentration of aquifer sediment in bulk

sample, (b) concentration of DNA extracted from filtered aquifer sediment, (c) $16 \mathrm{~S}$ rRNA copy numbers, and (d) ethB gene copies determined by qRT-PCR. * bdl symbol indicates values were below detection limits. Where error bars are shown, results are the mean + SD of technical replicates

higher in the attached than the planktonic phase ( $p=$ 0.034).

Subsequently, the ethB:16S rRNA gene copy number ratio was examined to deduce if the attached or planktonic fractions provided the most representative sample to determine ETBE biodegradation potential in these aquifers. At Site $\mathrm{T}$ the eth $B: 16 \mathrm{~S}$ rRNA ratio was typically $10 \mathrm{x}$ higher in the $5 \mu \mathrm{m}$ filtered samples than in the $0.2 \mu \mathrm{m}$-filtered samples $(p=$ 0.004 ). In wells F2 and T1, the ratio was $>0.1$ for the $5 \mu \mathrm{m}$ filtered samples (Fig. 4). In all cases where the $e t h B$ gene was

detectable in the $0.2 \mu \mathrm{m}$-filtered samples, it had an ethB:16S rRNA ratio $<0.1$.

High-throughput $16 \mathrm{~S}$ rRNA gene sequencing of the microbial communities from both field sites was performed. While community membership was similar between samples from the same monitoring wells, membership differed markedly (Supplementary Figure 2a). In general, ETBE-impacted monitoring wells from Site F (F2) and Site T (T1, T2, T3) were dominated by alpha-, delta- and gamma-Proteobacteria. The microbial community of the non-impacted monitoring well 
(F1) at Site F contained alpha and gamma-Proteobacteria but also Bacteroidia; the delta-Proteobacteria were much reduced (Supplementary Figure 3). Furthermore, while the microbial community membership of the attached and planktonic fractions was similar for each individual monitoring well (Supplementary Figure 2a), the relative abundance of these organisms changed with purging (Supplementary Figure 2b), confirming that the purging regime influenced the aquifer microbial community composition.

In the previous study (Nicholls et al. 2020) using microcosms constructed from Site F inocula, members of the Comamonadaceae, among others, were identified as organisms that increased in relative abundance (designated as 'responders') after exposure to ETBE. Regardless of the ETBE exposure history, members of the Comamonadaceae increased in abundance when exposed to ETBE. It was therefore hypothesised that this group of organisms was involved in ETBE biodegradation, either as primary degraders or as degraders of intermediate metabolites of ETBE. To determine if they were ubiquitous across the two ETBE-release sites sampled in this study, the OTUs identified in the microcosm study were compared with the field samples obtained from Site F and Site T (Supplementary Figure 4).

At Site F less than $1 \%$ of the total microbial community in monitoring well F1 (non-impacted) were identified as ETBEresponding organisms, whereas $>4 \%$ of the total microbial community in monitoring well F2 (ETBE-impacted) were previously characterised ETBE-responding organisms. Borehole purge volume had little effect on the relative abundance of these organisms (Supplementary Figure 4). At Site T members of the Comamonadaceae were identified in all three monitoring wells, albeit at varying abundances. It was noted that the presence of the ethB gene was not correlated with identified 'responders', for example the greatest abundance of responders was identified in monitoring well $\mathrm{T} 3$, yet the eth $B$ gene was below the detection limit. In all cases where ETBEresponding organisms were detected at $>1 \%$ relative abundance, most belong to the Gammaproteobacteria, in which members of the Comamonadaceae family are found. It should be noted that in the Nicholls et al. (2020) study, the Greengenes database was used for taxonomic identification, whereas in this study the Silva database was employed. Due to this change, the nomenclature of taxonomy differs between the two databases; Comamonadaceae are placed in the Betaproteobacteria class when using Greengenes, but are grouped in the Gammaproteobacteria class in the Silva database. While the nomenclature of taxonomy varies between the two studies, a $100 \%$ sequence identity match was required.

\section{Discussion}

\section{Groundwater monitoring to evaluate ETBE- biodegradation}

Concentrations of ETBE, TBA and dissolved oxygen are typically monitored in groundwater at ETBE-release sites to demonstrate aerobic biodegradation of ETBE (Rosell et al. 2005;
Fig. 4 Plot of $e t h B$ to $16 \mathrm{~S}$ rRNA gene copy number ratios for Site F, well F2, and Site T, wells T1 and $\mathrm{T} 2$, according to different purged borehole volumes (1, 3 or 6). Filled symbols represent the 5 $\mu \mathrm{m}$-filtered samples and open symbols represent the $0.2 \mu \mathrm{m}$ filtered samples. * bdl indicates that the $e t h B$ gene was below detection limit and a ratio was therefore not determined. Results are the mean $+/-$ SD of technical replicates

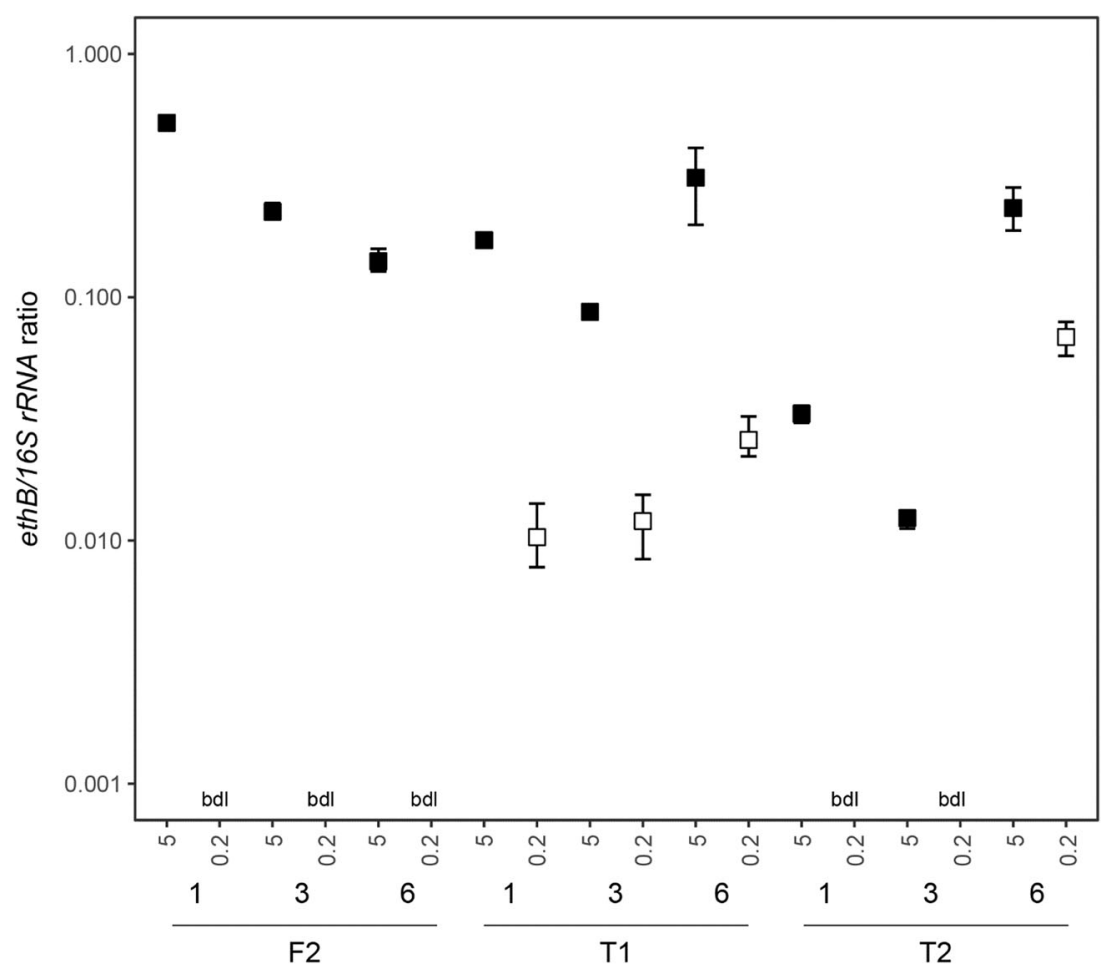


Fayolle-Guichard et al. 2012; Stupp et al. 2012; Bombach et al. 2015; van der Waals et al. 2018; Nicholls et al. 2020; Thornton et al. 2020). The detection of the ethB gene in aquifer samples can provide additional microbiological-based evidence to support the hydrochemical assessment, complementing other molecular tools which may be deployed to evaluate GEO biodegradation (e.g. Fayolle-Guichard et al. 2012; van der Waals et al. 2018; Kucharzyka et al. 2019; Kyselková et al. 2019). This is site specific and may be appropriate in cases where the hydrochemical assessment suggests that conditions are favourable for ETBE biodegradation but this is not observed, or the hydrochemical data is unclear, for example due to releases of multiple GEO. It should be noted that the presence of the eth $B$ gene in an aquifer is evidence for ETBE biodegradation potential. However, the absence of this gene does not imply the absence of this potential, as ETBE biodegradation could occur via other uncharacterised routes (Kyselková et al. 2019).

This study has shown that ETBE biodegradation potential cannot be characterised in groundwater-only samples by analysis of the ethB gene. However, several field-based approaches are available to sample the attached microbial community in an aquifer (Lehman 2007). These include the following:

1. Recovery of cored aquifer material and direct sampling of attached microorganisms (Lehman 2007; Lehman et al. 2004; Kieft 2010; Wilkins et al. 2014; Kiaalhosseini et al. 2016);

2. Incubation of native aquifer material, surrogate geological media (e.g. quartz sand, crushed rock), inert substrates (e.g. granular activated carbon), artificial platforms (e.g. sampling coupons) or in situ microcosms within a borehole or monitoring well and sampling the attached communities established after colonisation (Alfreider et al. 1997; Mandelbaum et al. 1997; Griebler et al. 2002; Lehman et al. 2004; Reardon et al. 2004; Hendrickx et al. 2005; Kovacik et al. 2006; Lehman 2007; Kästner and Richnow 2010; Aslett et al. 2011; Handley et al. 2012; Rizoulis et al. 2013; Smith et al. 2018; MujicaAlarcon et al. 2021); and

3. Mobilisation of attached microorganisms for sampling using downhole sonication techniques (Ugolini et al. 2014a; Close et al. 2020).

These methods typically require specialist equipment, are expensive, labour-intensive and time-consuming (Hendrickx et al. 2005; Lehman et al. 2004; Lehman 2007; Kieft 2010; Wilkins et al. 2014; Hug et al. 2015). The collection of core material is undoubtedly the gold standard for sampling the aquifer microbial community (Lehman 2007), but core recovery may be difficult in cohesionless sediments (e.g. sands and gravels) and is susceptible to fragmentation or contamination by the drilling methods used (Wilkins et al. 2014; Kiaalhosseini et al. 2016; Close et al. 2020), or requires elaborate measures to assess and avoid contamination during sampling (Lehman et al. 2004; Spence et al. 2005; Wilkins et al. 2014; Kallmeyer 2016; Friese et al. 2017). The destructive nature of core sampling also means temporal sampling is not possible for the same location (Lehman 2007; Wu et al. 2013). Methods using the incubation of materials within boreholes can provide similar results to core samples (Handley et al. 2012). However, results may also depend on the incubation time and compatibility between the material used with that in the aquifer, to ensure representative sampling (Lehman et al. 2004; Lehman 2007; Smith et al. 2018; Mujica-Alarcon et al. 2021). Hence, sampling methods which can potentially address these constraints are recommended (Smith et al. 2018). As shown in this study, the collection of a mixed groundwater and aquifer sediment slurry sample from a pumped monitoring well can provide reliable DNA yields from small sample volumes (e.g. 10-50 mL), which enable the detection of the $e t h B$ gene when present. Other studies have also proposed the collection of sediment fines in boreholes to sample attached microorganisms (Cardenas et al. 2008; Wu et al. 2013; Li et al. 2018). The current method offers advantages in enabling relatively rapid and repeat sampling of existing groundwater monitoring wells at a site. This can be implemented within the routine groundwater sampling of GEO-impacted aquifers to support the hydrochemical assessment undertaken. It may also be appropriate for sampling the aquifer microbial community when monitoring the efficacy of engineered remediation measures used for plume management (e.g. Wu et al. 2013). By simultaneously collecting both groundwater and aquifer sediment, it enables suspended and corresponding attached microorganisms to be sampled, as advocated in other studies (Griebler et al. 2002; Lehman 2007; Ugolini et al. 2014b; Smith et al. 2018). It may therefore provide a practical and cost-effective alternative to other borehole-based methods available to sample the aquifer microbial community. An important feature would be the availability of an established monitoring well network at a site for sampling. There is value in exploring the application of this sampling approach for other aquifer settings and contaminant-release scenarios, beyond that examined for ETBE in the current study. However, the method may not be appropriate in aquifers (e.g. crystalline rock sites) in which there is limited sediment input to the monitoring well during groundwater pumping.

\section{Location of ETBE-degrading organisms in aquifers}

While it is generally accepted that the attached and suspended microbial communities differ markedly, there is less understanding of the functionality of each fraction (Herrmann et al. 2017), especially for GEO biodegradation. Typically, functionality has been inferred from the presence of specific 
functional genes in microbial consortia (Wu et al. 2013; Smith et al. 2018). In the present study eth $B$ gene copy numbers were used as a direct indication of functional capability for ETBE biodegradation within the microbial community, and to infer the presence of ETBE-degrading organisms. Numerous studies have investigated GEO-degrading organisms that colonise a surface, for use in a bioreactor (Alfonso-Gordillo et al. 2016; Hicks et al. 2014; Kharoune 2001; Purswani et al. 2011), suggesting that these degraders can attach to inert surfaces. Fayolle-Guichard et al. (2012) investigated the use of a batch-fed pilot plant to treat ETBE-impacted groundwater and reported that eth $B$ gene copy numbers decreased without continual feeding. In their experiment a mixed culture was fixed to perlite and added to a bioreactor, with amendments of ETBE and BTEX. While ethB gene copy numbers increased with ETBE additions, they rapidly decreased once the substrate was consumed. It should be noted that only the water was sampled in the time-course experiment, even though the ETBE-degraders were initially fixed to perlite. It is therefore plausible that most of the ethB gene-containing organisms remained attached, but the addition of ETBE increased the $e t h B$ gene-containing organisms in the groundwater. This increase was probably caused by the translocation of new ETBE-degraders via dispersal (i.e. new cells that were yet to colonise a surface) and therefore the ETBE-degraders were transiently detected at higher concentrations in the water, but the number of these genes decreased rapidly as the microbes began to attach to a surface. Along with ETBE-degraders, TBA-degrading organisms have also been identified as surface attachers (Aslett et al. 2011). While such studies have shown that GEO-degrading organisms can attach, the current study provides evidence that ETBE-degraders preferentially attach to surfaces.

Based on the results of the microcosm experiments and ETBE-release sites investigated in this study, we conclude that: a) most cells are attached, as the vast majority of extracted DNA was obtained from the aquifer sediment fraction, and b) the eth $B$ gene was detected at higher gene copy numbers and the ethB:16S RNA ratio was higher in the aquifer sediment fraction, compared with the corresponding groundwater samples, i.e. the relative abundance of ETBE-degraders is greater in attached communities compared to planktonic communities. Therefore, sampling of the attached community is essential to determine the diversity and abundance of ETBE-degraders in the microbial community. Furthermore, given that the ethB gene was not detected in the planktonic fraction, but readily detected in the aquifer sediment fraction at Site $\mathrm{F}$, it is concluded that a sediment-free groundwater sample will not provide a representative sample for the presence of the gene at the site. At Site $\mathrm{T}$ the $e t h B$ gene was detected in both the planktonic and attached phases, although this was around ten times lower in the groundwater fraction. These observations were reinforced by the results of the purging experiment conducted at both field sites, which showed that generally less DNA was recovered after extensive purging (e.g. 6 well volumes) and in many cases the $e t h B$ gene copy number was higher in the early purges (1-3 well volumes) compared with 6 well volumes. This reflects the progressive removal of the sediment fraction from the groundwater sample with continued purging. It suggests that extended purging of monitoring wells prior to groundwater sampling, as supported within current site sampling protocols (e.g. Nielsen and Nielsen 2006; USEPA 2017), should be avoided if the aquifer ETBE biodegradation potential is assessed by the detection of the $e t h B$ gene. However, obtaining true aquifer samples is essential to avoid capturing samples that provide misleading results, i.e. well storage samples (Bonte et al. 2017). Hence, a balance between purging and aquifer sediment recovery must be achieved. Therefore, it is recommended that purging should be conducted until field parameters stabilise prior to sample collection. In the current study, less than 3 purge volumes were removed prior to sampling. Sampling regimes should emphasise the collection of aquifer sediment to prioritise the analysis of the attached microbial community for the presence of the $e t h B$ gene, according to the options outlined in the "Groundwater monitoring to evaluate ETBE-biodegradation" section. Considering practicality and cost, a mixed groundwater-sediment slurry sample obtained from monitoring wells after minimal purging can provide sufficient aquifer sediment for microbiological analysis of ETBE biodegradation potential via $e t h B$ gene detection.

Interestingly, ETBE was not detected in the last groundwater survey of both monitoring wells at Site F (December 2016), but was detected previously at $1.4 \mathrm{mg} \mathrm{L}^{-1}$ in well F2 (October 2016). Given that the field samples used in this study were collected in February 2019, the absence of ETBE at that time further supports the conclusion that the ETBE-degraders are attached to the aquifer sediment. This is because planktonic organisms would be redistributed by the groundwater flow, whereas the $e t h B$ gene-containing organisms would remain attached to the aquifer matrix at the location of this monitoring well. Furthermore, given that ETBE was not detected in groundwater for several years, this suggests that ETBEdegrading organisms persist in the aquifer once established, as reported by Nicholls et al. (2020).

\section{Geographical distribution of ETBE-degrading organ- isms at gasoline-release sites}

The organisms identified as 'responders' from the microcosm study in Nicholls et al. (2020) were compared with the sequencing data obtained from the Site F field samples in this study. In Nicholls et al. (2020) the microcosms were originally established using aquifer sediment and groundwater from Site F, and the same monitoring wells (F1 and F2) were re-sampled in the present study. The microcosm study identified OTUs predominantly belonging to the Comamonadaceae that increased in relative 
abundance when exposed to ETBE. The authors therefore hypothesised that the 'responders' were involved in aerobic biodegradation of ETBE. The re-sampling of Site F revealed that $\sim 4$ $\%$ of the microbial community from well $\mathrm{F} 2$ were the same 'responders' that were identified from the microcosm study (Supplementary Figure 4), with most belonging to the Comamonadaceae. Interestingly, a study investigating the bacterial colonisation of pristine sediments reported that members of the Comamonadaceae were early colonisers and therefore dominated the final microbial communities (Fillinger et al. 2019). Furthermore, in a recent study, van der Waals et al. (2019) identified Comamonadaceae as an abundant bacterial group in a mixed algal-bacterial culture obtained from contaminated groundwater that biodegraded ETBE in a batch reactor, suggesting that these microorganisms may play an important role in ETBE metabolism. To assess if the same microcosm 'responders' were identifiable at another ETBE-release site, this data was compared with Site $\mathrm{T}$ field data. At Site $\mathrm{T}$ the ethB gene was detected in well T1 but low numbers of ETBEresponders were evident and, conversely, where no eth $B$ gene was detected ETBE-responders were most dominant, with these organisms primarily belonging to the Gammaproteobacteria (well T3). This result suggests that the detection of specific organisms is less important that the detection of the degradative gene $(e t h B)$, i.e. that taxonomic analysis of a given microbial community is less reliable than the analysis of functional capability, based on the detection of the ethB gene within the consortia. Hence, the taxonomic composition of the microbial community may not indicate ETBE biodegradation potential. This has been attributed to the functional redundancy of ETBE-degrading consortia, in that the distribution of the ethB gene within the microbial community may be independent of its taxonomic composition (Kyselková et al. 2019). It implies that many bacterial species in a consortium could facilitate ETBE biodegradation, according to their functional capability. The exchange of genetic traits in a biofilm environment is considered advantageous in conserving degradative function (Singh et al. 2006; Rizoulis et al. 2013). In the case of ETBE the eth operon is flanked by two identical transposons and is readily lost under non-selective conditions (Chauvaux et al. 2001). Therefore, close proximity of microbes in a biofilm could facilitate the horizontal transfer of the eth gene cluster between different bacterial species within the attached microbial community (Singh et al. 2006; Kyselková et al. 2019).

\section{Conclusion}

This study has shown that under both laboratory and field conditions ETBE-degrading organisms in aquifers may preferentially attach to the aquifer substratum. This result has important implications for (i) sampling protocols aimed at characterising the aquifer ETBE biodegradation potential at ETBE-release sites, and (ii) the performance assessment of management measures such as natural attenuation or bioremediation, using microbiological-based analyses of ETBE biodegradation. In this context, the analysis of the $e t h B$ gene in the aquifer microbial community can provide additional evidence to support the hydrochemical assessment of aerobic ETBE biodegradation in groundwater at ETBE-release sites. The detection of the ethB gene in samples is a better function-based indicator of the aquifer ETBE biodegradation potential than the taxonomic composition of the microbial community. However, the evidence from this study indicates strongly that sampling solely the planktonic community in groundwater is not a reliable measure of the presence of ETBE-degrading organisms, nor an indicator of ETBE biodegradation potential in the aquifer microbial community. The low DNA recovery from the planktonic phase found in this study suggests large volumes (e.g. $>2 \mathrm{~L}$ ) of groundwater would be required for $e t h B$ gene detection, where no aquifer sediment is available. Furthermore, even when the eth $B$ gene is detected in groundwater, its relative abundance is approximately ten-fold less than in the attached community, which may result in misleading inferences on ETBE biodegradation potential. Therefore, sampling of the attached microbial community should be prioritised for this microbiological assessment. A groundwateraquifer sediment slurry sample obtained from a pumped monitoring well can provide a sample of the aquifer microbial community for the analysis of ETBE biodegradation potential and temporal development of the ETBE-degrading community. This sample should be collected after minimal purging of the monitoring well once field parameters have stabilised, to ensure a representative well sample is obtained and to maximise the recovery of the aquifer sediment fraction, and therefore DNA yield and detection of the $e t h B$ gene. This is a relatively rapid and costeffective method to obtain samples for this microbiological assessment.

Supplementary Information The online version contains supplementary material available at https://doi.org/10.1007/s11356-021-15606-7.

Acknowledgements This research was completed within a project designed and funded by Concawe (www.concawe.eu), which is the scientific division of the European Petroleum Refiners Association, under contract 201601270. The authors acknowledge the support and advice of Birgitta Beuthe, Sandrine Demeure, Martyn Dunk, Céline Pisano, Thomas Grosjean and Jonathan Smith from the Concawe Soil and Groundwater Task Force (STF33) in the preparation of the manuscript.

Author contribution Nicholls: methodology, validation, formal analysis, investigation, data curation, writing — original draft, writing — review and editing, visualization; Rolfe: conceptualization, methodology, formal analysis, data curation, writing - original draft, writing - review and editing, visualization, supervision; Mallinson: methodology, validation, formal analysis, investigation; Bonte: project administration, resources; Hjort: project administration, resources; Spence: Conceptualization, 
project administration, methodology, resources; Thornton: conceptualization, methodology, writing - original draft, writing - review and editing, supervision, funding acquisition

Funding The following statement is included in the acknowledgements for the manuscript:

This research was completed within a project designed and funded by Concawe (www.concawe.eu), which is the scientific division of the European Petroleum Refiners Association, under contract 201601270. The authors acknowledge the support and advice of Birgitta Beuthe, Sandrine Demeure, Martyn Dunk, Céline Pisano, Thomas Grosjean and Jonathan Smith from the Concawe Soil and Groundwater Task Force (STF33) in the preparation of the manuscript.

Data availability The datasets generated and analysed during the current study are available in the SRA repository, PRJNA720508, which can be accessed via https://www.ncbi.nlm.nih.gov/sra/PRJNA720508.

\section{Declarations}

Ethics approval and consent to participate Not applicable

Consent for publication Not applicable

Competing interests The authors declare no competing interests.

Open Access This article is licensed under a Creative Commons Attribution 4.0 International License, which permits use, sharing, adaptation, distribution and reproduction in any medium or format, as long as you give appropriate credit to the original author(s) and the source, provide a link to the Creative Commons licence, and indicate if changes were made. The images or other third party material in this article are included in the article's Creative Commons licence, unless indicated otherwise in a credit line to the material. If material is not included in the article's Creative Commons licence and your intended use is not permitted by statutory regulation or exceeds the permitted use, you will need to obtain permission directly from the copyright holder. To view a copy of this licence, visit http://creativecommons.org/licenses/by/4.0/.

\section{ReferencesEnvironment Age}

Alfonso-Gordillo G, Flores-Ortiz CM, Morales-Barrera L, CristianiUrbina E (2016) Biodegradation of methyl tertiary butyl ether (MTBE) by a microbial consortium in a continuous up-flow packed-bed biofilm reactor: kinetic study, metabolite identification and toxicity bioassays. PLoS One 11:e0167494. https://doi.org/10. 1371/journal.pone.0167494

Alfreider A, Krössbacher M, Psenner R (1997) Groundwater samples do not reflect bacteiral densitiesand activity in subsurface systems. Water Res 31:832-840

Anantharaman K, Brown CT, Hug LA, Sharon I, Castelle CJ, Probst AJ, Thomas BC, Singh A, Wilkins MJ, Karaoz U, Brodie EL, Williams KH, Hubbard SS, Banfield JF (2016) Thousands of microbial genomes shed light on interconnected biogeochemical processes in an aquifer system. Nat Commun 7:13219. https://doi.org/10.1038/ ncomms 13219

API (2007) Technical protocol for evaluating the natural attenuation of MtBE. American Petroleum Institute publication, New York 4761, pp 186

Aslett D, Haas J, Hyman M (2011) Identification of tertiary butyl alcohol (TBA)-utilizing organisms in BioGAC reactors using 13C-DNA stable isotope probing. Biodegradation 22:961-972. https://doi. org/10.1007/s10532-011-9455-3

ASTM (1998) Standard guide for remediation of groundwater by natural attenuation at petroleum release sites. American Society for Testing Materials Designation E, West Conshohocken, pp 1943-98

Ben Maama S, Aquilina L, Quaiser A, Pauwels H, Michon-Coudouel S, Vergnaud-Ayraud V, Labasque T, Roques C, Abbott BW, Dufresne A (2015) Groundwater isolation governs chemistry and microbial community structure along hydrologic flowpaths. Front Microbiol. https://doi.org/10.3389/fmicb.2015.01457

Bodenhausen N, Horton MW, Bergelson J (2013) Bacterial communities associated with the leaves and the roots of Arabidopsis thaliana. PLoS One 8:e56329. https://doi.org/10.1371/journal.pone.0056329

Bolyen E, Rideout JR, Dillon MR, Bokulich NA, Abnet CC, Al-Ghalith GA, Alexander H, Alm EJ, Arumugam M, Asnicar F, Bai Y, Bisanz JE, Bittinger K, Brejnrod A, Brislawn CJ, Brown CT, Callahan BJ, Caraballo-Rodríguez AM, Chase J, Cope EK, Da Silva R, Diener C, Dorrestein PC, Douglas GM, Durall DM, Duvallet C, Edwardson CF, Ernst M, Estaki M, Fouquier J, Gauglitz JM, Gibbons SM, Gibson DL, Gonzalez A, Gorlick K, Guo J, Hillmann B, Holmes S, Holste H, Huttenhower C, Huttley GA, Janssen S, Jarmusch AK, Jiang L, Kaehler BD, Kang KB, Keefe CR, Keim P, Kelley ST, Knights D, Koester I, Kosciolek T, Kreps J, Langille MGI, Lee J, Ley R, Liu Y-X, Loftfield E, Lozupone C, Maher M, Marotz C, Martin BD, McDonald D, McIver LJ, Melnik AV, Metcalf JL, Morgan SC, Morton JT, Naimey AT, Navas-Molina JA, Nothias LF, Orchanian SB, Pearson T, Peoples SL, Petras D, Preuss ML, Pruesse E, Rasmussen LB, Rivers A, Robeson MS, Rosenthal P, Segata N, Shaffer M, Shiffer A, Sinha R, Song SJ, Spear JR, Swafford AD, Thompson LR, Torres PJ, Trinh P, Tripathi A, Turnbaugh PJ, Ul-Hasan S, van der Hooft JJJ, Vargas F, VázquezBaeza Y, Vogtmann E, von Hippel M, Walters W, Wan Y, Wang M, Warren J, Weber KC, Williamson CHD, Willis AD, Xu ZZ, Zaneveld JR, Zhang Y, Zhu Q, Knight R, Caporaso JG (2019) Reproducible, interactive, scalable and extensible microbiome data science using QIIME 2. Nat Biotechnol 37:852-857. https://doi.org/ 10.1038/s41587-019-0209-9

Bombach P, Nägele N, Rosell M, Richnow HH, Fischer A (2015) Evaluation of ethyl tert-butyl ether biodegradation in a contaminated aquifer by compound-specific isotope analysis and in situ microcosms. J Hazard Mater 286:100-106. https://doi.org/10.1016/j. jhazmat.2014.12.028

Bonte M, Wols B, Maas K, Stuyfzand P (2017) Sources of dissolved oxygen in monitoring and pumping wells. Hydrogeol J 25:55-66. https://doi.org/10.1007/s10040-016-1477-9

Callahan BJ, McMurdie PJ, Rosen MJ, Han AW, Johnson AJA, Holmes SP (2016) DADA2: High-resolution sample inference from Illumina amplicon data. Nat Methods 13:581-583. https://doi.org/10.1038/ nmeth.3869

Cardenas E, Wu W-M, Leigh MB, Carley J, Carroll S, Gentry T, Luo J, Watson D, Gu B, Ginder-Vogel M, Kitanidis PK, Jardine PM, Zhou J, Criddle CS, Marsh TL, Tiedje JM (2008) Microbial communities in contaminated sediments, associated with bioremediation of uranium to submicromolar levels. Appl Environ Microbiol 74:37183729. https://doi.org/10.1128/AEM.02308-07

Chauvaux S, Chevalier F, Le Dantec C, Fayolle F, Miras I, Kunst F, Beguin P (2001) Cloning of a genetically unstable cytochrome P450 gene cluster involved in degradation of the pollutant ethyl tertbutyl ether by Rhodococcus ruber. J Bacteriol 183:6551-6557. https://doi.org/10.1128/JB.183.22.6551-6557.2001

CL:AIRE (2008) Principles and practice for the collection of representative groundwater samples. CL:AIRE Technical Bulletin TB3, pp 8. www.claire.co.uk

Close M, Abraham P, Webber J, Cowey E, Humphries B, Fenwick G, Howard S, Huynh K, Grace T, Dupont P, Weaver L (2020) Use of sonication for enhanced sampling of attached microbes from 
groundwater systems. Groundwater 58:901-912. https://doi.org/10. 1111/gwat.12984

Cullimore DR (2007) Practical Manual of Groundwater Microbiology, Practical Manual of Groundwater Microbiology. CRC Press, Boca Raton. https://doi.org/10.1201/9781420008166

Environment Agency (2000) Guidance on the assessment and monitoring of natural attenuation of contaminants in groundwater. Environment Agency R\&D Publication 95. Environment Agency, Bristol http:// webarchive.nationalarchives.gov.uk/20140328084622/https:// publications.environment-agency.gov.uk/ms/6WGI4

Environment Agency (2003a) Guidance on the monitoring of landfill leachate, groundwater and surface water. Landfill Technical Guidance Note 02

Environment Agency (2003b) Development of a methodology for selection of determinant suites and sampling frequency for groundwater quality monitoring. Environment Agency, ISBN1857 05864X, pp. 102

Environmental Protection Authority (2019) Guidelines for regulatory monitoring and testing - Groundwater sampling. EPA South Australia, Adelaide, p 61

Eriksson L, Edlund J, Johansson L, Rabe L, Bengtsson A, Pedersen K (2016) Methods for sampling and analysis of attached and planktonic microorganisms in deep granitic rock aquifers, Swedish Nuclear Fuel and Waste Management Co., SKB Report R-16-09, pp.54. ISSN 1402-3091

Fayolle-Guichard F, Durand J, Cheucle M, Rosell M, Michelland RJ, Tracol J-P, Le Roux F, Grundman G, Atteia O, Richnow HH, Dumestre A, Benoit Y (2012) Study of an aquifer contaminated by ethyl tert-butyl ether (ETBE): Site characterization and on-site bioremediation. J Hazard Mater 201-202:236-243. https://doi.org/ 10.1016/j.jhazmat.2011.11.074

Fillinger L, Zhou Y, Kellermann C, Griebler C (2019) Non-random processes determine the colonization of groundwater sediments by microbial communities in a pristine porous aquifer. Environ Microbiol 21:327-342. https://doi.org/10.1111/1462-2920.14463

Friese A, Kallmeyer J, Kitte JA, Martínez IM, Bijaksana S, Wagner D (2017) A simple and inexpensive technique for assessing contamination during drilling operations. Limnol Oceanogr Methods 15: 200-211. https://doi.org/10.1002/lom3.10159

Gregory SP, Maurice LD, West JM, Gooddy DC (2014) Microbial communities in UK aquifers: current understanding and future research needs. Q J Eng Geol Hydrogeol 47:145-157. https://doi.org/10. 1144/qjegh2013-059

Griebler C, Mindl B, Slezak D, Geiger-Kaiser M (2002) Distribution patterns of attached and suspended bacteria in pristine and contaminated shallow aquifers studied with an in situ sediment exposure microcosm. Aquat Microb Ecol 28:17-129

Guisado IM, Purswani J, Catón-Alcubierre L, González-López J, Pozo C (2016) Toxicity and biofilm-based selection for methyl tert-butyl ether bioremediation technology. Water Sci Technol 74:2889 2897. https://doi.org/10.2166/wst.2016.461

Gunasekaran V, Donmez E, Girhard M, Urlacher VB, Constantí M (2014) Biodegradation of fuel oxygenates and their effect on the expression of a newly identified cytochrome P450 gene in Achromobacter xylosoxidans MCM2/2/1. Process Biochem 49: 124-129. https://doi.org/10.1016/j.procbio.2013.09.028

Handley KH, Wrighton KC, Piceno YM, Andersen GL, DeSantis TZ, Williams KH, Wilkins MJ, N'Guessan AL, Peacock A, Bargar J, Long PE, Banfield JF (2012) High-density PhyloChip profiling of stimulated aquifer microbial communities reveals a complex response to acetate amendment. FEMS Microbiol Ecol 81:188-204. https://doi.org/10.1111/j.1574-6941.2012.01363.x

Harter T, Watanabe N, Li X, Atwill ER, Samuels W (2014) Microbial groundwater sampling protocol for fecal-rich environments. Groundwater 52:126-136. https://doi.org/10.1111/gwat.12222
Hendrickx B, Dejonghe W, Boënne W, Brennerova M, Cernik M, Lederer T, Bucheli-Witschel M, Bastiaens L, Verstraete W, Top EM, Diels L, Springael D (2005) Dynamics of an oligotrophic bacterial aquifer community during contact with a groundwater plume contaminated with benzene, toluene, ethylbenzene, and xylenes: an In situ mesocosm study. Appl Environ Microbiol 71:3815-3825. https://doi.org/10.1128/AEM.71.7.3815-3825.2005

Herrmann M, Opitz S, Harzer R, Totsche K, Küsel K (2017) Attached and suspended denitrifier communities in pristine limestone aquifers harbor high fractions of potential autotrophs oxidizing reduced iron and sulfur compounds. Microb Ecol 74:264-277. https://doi.org/10. 1007/s00248-017-0950-x

Hicks KA, Schmidt R, Nickelsen MG, Boyle SL, Baker JM, Tornatore PM, Hristova KR, Scow KM (2014) Successful treatment of an MTBE-impacted aquifer using a bioreactor self-colonized by native aquifer bacteria. Biodegradation 25:41-53. https://doi.org/10.1007/ s10532-013-9639-0

Hose GC, Lategan MJ (2012) Sampling strategies for biological assessment of groundwater ecosystems. Cooperative Research Centre for Contamination Assessment and Remediation of the Environment, Technical Report series, no. 21, pp 32

Hug LA, Thomas BC, Brown CT, Frischkorn KR, Williams KH, Tringe SG, Banfield JF (2015) Aquifer environment selects for microbial species cohorts in sediment and groundwater. ISME J 9:1846-1856. https://doi.org/10.1038/ismej.2015.2

Imfeld G, Pieper H, Shani N, Rossi P, Nikolausz M, Nijenhuis I, Paschke H, Weiss H, Richnow HH (2011) Characterization of groundwater microbial communities, dechlorinating bacteria, and in situ biodegradation of chloroethenes along a vertical gradient. Water Air Soil Pollut 221:107-122. https://doi.org/10.1007/s11270-011-0774-0

Itävaara M, Nyyssönen M, Kapanen A, Nousiainen A, Ahonen L, Kukkonen I (2011) Characterization of bacterial diversity to a depth of $1500 \mathrm{~m}$ in the Outokumpu deep borehole, Fennoscandian Shield. FEMS Microbiol Ecol 77:295-309

Kallmeyer J (2016) Contamination control for scientific drilling operations. Adv Appl Microbiol 98:61-91. https://doi.org/10.1016/bs. aambs.2016.09.003

Kästner M, Richnow H (2010) In situ microcosm studies to characterize microbial processes in the field. In: Timmis KN (ed) Handbook of Hydrocarbon and Lipid Microbiology. Springer, Berlin, pp 35033511. https://doi.org/10.1007/978-3-540-77587-4 273

Katoh K, Rozewicki J, Yamada KD (2019) MAFFT online service: multiple sequence alignment, interactive sequence choice and visualization. Brief Bioinform 20:1160-1166. https://doi.org/10.1093/bib/ bbx 108

Kharoune M (2001) Aerobic biodegradation of an oxygenates mixture: ETBE, MTBE and TAME in an upflow fixed-bed reactor. Water Res 35:1665-1674. https://doi.org/10.1016/S0043-1354(00)004486

Kiaalhosseini S, Johnson RL, Rogers RC, Renno MI, Lyverse M, Sale TC (2016) Cryogenic core collection (C3) from unconsolidated subsurface media. Ground Water Monit Remediat 36:41-49. https:// doi.org/10.1111/gwmr.12186

Kieft TL (2010) Sampling the deep sub-surface using drilling and coring techniques. In: Timmis KN (ed) Handbook of Hydrocarbon and Lipid Microbiology. Springer, Berlin, pp 3427-3441. https://doi. org/10.1007/978-3-540-77587-4 267

Korbel K, Chariton A, Stephenson S, Greenfield P, Hose GC (2017) Wells provide a distorted view of life in the aquifer: implications for sampling, monitoring and assessment of groundwater ecosystems. Sci Rep 7:40702. https://doi.org/10.1038/srep40702

Kovacik WP, Takai K, Mormile MR, McKinley JP, Brockman FJ, Fredrickson JK, Holben WE (2006) Molecular analysis of deep subsurface Cretaceous rock indicates abundant $\mathrm{Fe}(\mathrm{III})$ - and $\mathrm{S}^{0}$-reducing bacteria in a sulfate-rich environment. Environ Microbiol 8: $141-155$ 
Kozuskanich J, Novakowski KS, Anderson BC (2011) Fecal Indicator Bacteria Variability in Samples Pumped from Monitoring Wells. Ground Water 49(1):43-52. https://doi.org/10.1111/j.1745-6584. 2010.00713.x

Kucharzyka KH, Rectanus HV, Bartling CM, Rosansky S, MinardSmitha A, Mullins LA, Neil K (2019) Use of omic tools to assess methyl tert-butyl ether (MTBE) degradation in groundwater. J Hazard Mater 378:120618

Kyselková M, Falcão Salles J, Dumestre A, Benoit Y, Grundmann GL (2019) Distinct bacterial consortia established in ETBE-degrading enrichments from a polluted aquifer. Appl Sci 9:4247-4263. https:// doi.org/10.3390/app9204247

Le Digabel Y, Demanèche S, Benoit Y, Vogel TM, Fayolle-Guichard F (2013) Ethyl tert-butyl ether (ETBE) biodegradation by a syntrophic association of Rhodococcus sp. IFP 2042 and Bradyrhizobium sp. IFP 2049 isolated from a polluted aquifer. Appl Microbiol Biotechnol 97:10531-10539. https://doi.org/10.1007/s00253-0134803-3

Lebron CA, Petrovskis E, Loeffler F, Henn K (2011) Guidance protocol: Application of nucleic acid-based tools for monitoring Monitored Natural Attenuation (MNA), biostimulation, and bioaugmentation at chlorinated solvent sites. Naval Facilities Engineering Command, Engineering Service Center, Environmental Restoration Project ER-0518, pp 36

Lehman RM (2007) Understanding of aquifer microbiology is tightly linked to sampling approaches. Geomicrobiol J 24:331-341. https://doi.org/10.1080/01490450701456941

Lehman RM, Colwell FS, Bala GA (2001) Attached and unattached microbial communities in a simulated basalt aquifer under fracture- and porous-flow conditions. Appl Environ Microbiol 67: 2799-2809. https://doi.org/10.1128/AEM.67.6.2799-2809.2001

Lehman RM, O'Connell SP, Banta A, Fredrickson JK, Reysenbach A-L, Kieft TL, Colwell FS (2004) Microbiological comparison of core and groundwater samples collected from a fractured basalt aquifer with that of dialysis chambers incubated in situ. Geomicrobiol J 21: 169-182. https://doi.org/10.1080/01490450490275848

Lenth RV (2021) emmeans: Estimated Marginal Means, aka LeastSquares Means. R package version 1.6.0. https://CRAN.R-project. org $/$ package $=$ emmeans

Li B, Wu W-M, Watson DB, Cardenas E, Chao Y, Phillips DH, Mehlhorn T, Lowe K, Kelly SD, Li P, Tao H, Tiedje JM, Criddle CS, Tong Zhang T (2018) Bacterial community shift and coexisting/ coexcluding patterns revealed by network analysis in a uraniumcontaminated site after bioreduction followed by reoxidation. Appl Environ Microbiol 84:e02885-e02817. https://doi.org/10.1128/ AEM.02885-17

Malandain C, Fayolle-Guichard F, Vogel TM (2010) Cytochromes P450mediated degradation of fuel oxygenates by environmental isolates. FEMS Microbiol Ecol 72:289-296. https://doi.org/10.1111/j.15746941.2010.00847.x

Mandelbaum RT, Shati MR, Ronen D (1997) In situ microcosms in aquifer bioremediation studies. FEMS Microbiol Rev 20:489-502. https://doi.org/10.1111/j.1574-6976.1997.tb00332.x

McMurdie PJ, Holmes S (2013) phyloseq: An R package for reproducible interactive analysis and graphics of microbiome census data. PLoS One 8:e61217. https://doi.org/10.1371/journal.pone.0061217

Mujica-Alarcon JF, Thornton SF, Rolfe SA (2021) Long-term dynamic changes in attached and planktonic microbial communities in a contaminated aquifer. Environ Pollut 277:116765. https://doi.org/10. 1016/j.envpol.2021.116765

Nicholls HCG, Mallinson HEH, Rolfe SA, Hjort M, Spence MJ, Thornton SF (2020) Influence of contaminant exposure on the development of aerobic ETBE biodegradation potential in microbial communities from a gasoline-impacted aquifer. J Hazard Mater 388: 122022. https://doi.org/10.1016/j.jhazmat.2020.122022
Nielsen DM, Nielsen G (2006) Preparing sampling points for sampling: Purging methods. In: The Essential Handbook of Ground-Water Sampling. Chapter 4. CRC Press, Boca Raton, p 32. https://doi. org/10.1201/9781420042795

O'Dwyer J, Dowling A, Adley CC (2014) Microbiological assessment of private groundwater-derived potable water supplies in the Mid-West Region of Ireland. J Water Health 12:310-317. https://doi.org/10. 2166/wh.2014.178

Pedregosa F, Varoquaux G, Gramfort A, Michel V, Thirion B, Grisel O, Blondel M, Prettenhofer P, Weiss R, Dubourg V, Vanderplas J, Passos A, Cournapeau D, Brucher M, Perrot M, Duchesnay É (2011) Scikit-learn: Machine learning in Python. J Mach Learn Res 12:2825-2830

Price MN, Dehal PS, Arkin AP (2010) FastTree 2 - Approximately maximum-likelihood trees for large alignments. PLoS One 5: e9490. https://doi.org/10.1371/journal.pone.0009490

Purswani J, Juárez B, Rodelas B, Gónzalez-López J, Pozo C (2011) Biofilm formation and microbial activity in a biofilter system in the presence of MTBE, ETBE and TAME. Chemosphere 85:616624. https://doi.org/10.1016/j.chemosphere.2011.06.106

Quast C, Pruesse E, Yilmaz P, Gerken J, Schweer T, Yarza P, Peplies J, Glöckner FO (2012) The SILVA ribosomal RNA gene database project: improved data processing and web-based tools. Nucleic Acids Res 41:D590-D596. https://doi.org/10.1093/nar/gks1219

R Core Team. (2019). R: A Language and Environment for Statistical Computing. Vienna. https://www.r-project.org/

R Core Team (2020) R: A language and environment for statistical computing. R Foundation for Statistical Computing, Vienna https:// www.R-project.org/

Reardon CL, Cummings DE, Petzke LM, Kinsall BL, Watson DB, Peyton BM, Geesey GG (2004) Composition and diversity of microbial communities recovered from surrogate minerals incubated in an acidic uranium-contaminated aquifer. Appl Environ Microbiol 70:6037-6046. https://doi.org/10.1128/AEM.70.10.6037-6046. 2004

Rizoulis A, Elliott DR, Rolfe SA, Thornton SF, Banwart SA, Pickup RW, Scholes JD (2013) Diversity of planktonic and attached bacterial communities in a phenol-contaminated sandstone aquifer. Microb Ecol 66:84-95. https://doi.org/10.1007/s00248-013-0233-0

Rohwerder T, Breuer U, Benndorf D, Lechner U, Muller RH (2006) The alkyl tert-butyl ether intermediate 2-hydroxyisobutyrate is degraded via a novel cobalamin-dependent mutase pathway. Appl Environ Microbiol 72:4128-4135. https://doi.org/10.1128/AEM.00080-06

Rosell M, Lacorte S, Forner C, Rohns H-P, Irmscher R, Barceló D (2005) Fate of gasoline oxygenates in conventional and multilevel wells of a contaminated groundwater table in Düsseldorf, Germany. Environ Toxicol Chem 24:2785-2795. https://doi.org/10.1897/05-080R.1

Rosell M, Lacorte S, Barceló D (2007) Occurrence and fate of MTBE in the aquatic environment over the last decade. In: Barceló D (ed) Fuel Oxygenates - Handbook of Environmental Chemistry, Water Pollution, vol 5. Springer Verlag, Berlin, pp 31-56

Rosell, M., Gonzalez-Olmos, R., Rohwerder, T. Rusevova, K., Georgi, A., Kopinke, F-D. and Richnow, H. H (2012). Critical evaluation of the 2D-CSIA scheme for distinguishing fuel oxygenate degradation reaction mechanisms. Environ Sci Technol, 46, 4757-4766. doi: https://doi.org/10.1021/es2036543

Roudnew B, Lavery TJ, Seymour JR, Jeffries TC, Mitchell JG (2014) Variability in bacteria and virus-like particle abundances during purging of unconfined aquifers. Groundwater 52:118-124. https:// doi.org/10.1111/gwat.12044

Schuster J, Schafer F, Hubler N, Brandt A, Rosell M, Hartig C, Harms H, Muller RH, Rohwerder T (2012) Bacterial degradation of tert-amyl alcohol proceeds via hemiterpene 2-methyl-3-buten-2-ol by employing the tertiary alcohol desaturase function of the rieske nonheme mononuclear iron oxygenase MdpJ. J Bacteriol 194:972-981. https://doi.org/10.1128/JB.06384-11 
Shah NW, Thornton SF, Bottrell SH, Spence MJ (2009) Biodegradation potential of MTBE in a fractured chalk aquifer under aerobic conditions in long-term uncontaminated and contaminated aquifer microcosms. J Contam Hydrol 103:119-133

Singh R, Paul D, Jain RK (2006) Biofilms: implications in bioremediation. Trends Microbiol 14:389-397. https://doi.org/10.1016/j.tim. 2006.07.001

Smith HJ, Zelaya AJ, De León KB, Chakraborty R, Elias DA, Hazen TC, Arkin AP, Cunningham AB, Fields MW (2018) Impact of hydrologic boundaries on microbial planktonic and biofilm communities in shallow terrestrial subsurface environments. FEMS Microbiol Ecol 94. https://doi.org/10.1093/femsec/fiy191

Somaratne N, Hallas G (2015) Review of risk status of groundwater supply wells by tracing the source of coliform contamination. Water 7:3878-3905. https://doi.org/10.3390/w7073878

Sorensen JPR, Maurice L, Edwards FK, Lapworth DJ, Read DS, Allen D, Butcher AS, Newbold LK, Townsend BR, Williams PJ (2013) Using boreholes as windows into groundwater ecosystems. PLoS One 8:e70264. https://doi.org/10.1371/journal.pone.0070264

Spence MJ, Thornton SF, Bottrell SH, Spence KH (2005) Determination of interstitial water chemistry and porosity in consolidated aquifer materials by diffusion equilibrium-exchange as an alternative to centrifugation. Environ Sci Technol 39:1158-1166

Stupp D, Gass M, Leiteritz H, Pijls C, Thornton SF, Smith JWN, Dunk M, Grosjean T, Den Haan KH (2012) Gasoline ether oxygenate occurrence in Europe, and a review of their fate and transport characteristics in the environment, CONCAWE Report 4/12. CONCAWE, Brussels https://www.concawe.eu/wp-content/ uploads/2017/01/report-no-4_12.pdf

Thornton SF, Morgan PM, Rolfe SA (2016) Bioremediation of hydrocarbons and chlorinated solvents in groundwater. In: McGenity TJ, Timmis KN, Nogales B (eds) Protocols for Hydrocarbon and Lipid Microbiology. Springer Verlag, Berlin. Series ISSN 19492448, pp 1-54. https://doi.org/10.1007/8623_2016_207

Thornton SF, Nicholls HCG, Rolfe S, Mallinson HEH, Spence MJ (2020) Biodegradation and fate of ethyl tert-butyl ether (ETBE) in soil and groundwater: A review. J Hazard Mater 391:122046. https://doi.org/ 10.1016/j.jhazmat.2020.122046

Tissen C, Benz SA, Menberg K, Bayer P, Blum P (2019) Groundwater temperature anomalies in central Europe. Environ Res Lett 14: 104012. https://doi.org/10.1088/1748-9326/ab4240

Ugolini F, Henneberger R, Bürgmann H, Zeyer J, Schroth MH (2014a) In-situ sonication for enhanced recovery of aquifer microbial communities. Groundwater 52:737-747. https://doi.org/10.1111/gwat. 12105
Ugolini F, Schroth MH, Bürgmann H, Zeyer J (2014b) Physical extraction of microorganisms from water-saturated, packed sediment. Water Environ Res 86:407-416. https://doi.org/10.2175/ $106143013 \times 13807328848216$

USEPA (1996) Low-Flow (minimal drawdown) groundwater sampling procedures. EPA 540/S-95/504. Office of Solid Waste and Emergency Response, Washington, DC

USEPA (2017) Procedures for groundwater sampling in the laboratory services and applied science division. Report 905 K, 04/26/2017, SESDPROC-301-R4, pp 34

van der Waals MJ, Pijls C, Sinke AJC, Langenhoff AAM, Smidt H, Gerritse J (2018) Anaerobic degradation of a mixture of MtBE, EtBE, TBA, and benzene under different redox conditions. Appl Microbiol Biotechnol 102:3387-3397. https://doi.org/10.1007/ s00253-018-8853-4

van der Waals MJ, Plugge C, Meima-Franke M, de Waard P, Bodelier PLE, Smidt H, Gerritse J (2019) Ethyl tert-butyl ether (EtBE) degradation by an algal-bacterial culture obtained from contaminated groundwater. Water Res 148:314-323

Warren J (2005) Representativeness of environmental samples. Environ Forensic 6:21-25. https://doi.org/10.1080/15275920590913868

Wiedemeier TH, Rifai HS, Newell CJ, Wilson JT (1999) Natural attenuation of fuels and chlorinated solvents in the subsurface. Wiley, New York $617 \mathrm{pp}$

Wilkins MJ, Daly RA, Mouser PJ, Trexler R, Sharma S, Cole DR, Wrighton KC, Biddle JF, Denis EH, Fredrickson JK, Kieft TL, Onstott TC, Peterson L, Pfiffner SM, Phelps TJ, Schrenk MO (2014) Trends and future challenges in sampling the deep terrestrial biosphere. Front Microbiol 5(481):8. https://doi.org/10.3389/fmicb. 2014.00481

Williamson WM, Close ME, Leonard MM, Webber JB, Lin S (2012) Groundwater biofilm dynamics grown in situ along a nutrient gradient. Ground Water 50:690-703. https://doi.org/10.1111/j.17456584.2011.00904.x

Wu W-M, Watsonc DB, Luod J, Carley J, Mehlhorn T, Kitanidis PK, Jardine PM, Criddle CS (2013) Surge block method for controlling well clogging and sampling sediment during bioremediation. Water Res 47:6566-6573

Wu X, Holmfeldt K, Hubalek V, Lundin D, Åström M, Bertilsson S, Dopson M (2016) Microbial metagenomes from three aquifers in the Fennoscandian shield terrestrial deep biospherefreveal metabolic partitioning among populations. ISME J 10:1192-1203

Publisher's note Springer Nature remains neutral with regard to jurisdictional claims in published maps and institutional affiliations. 